\title{
High carbon sequestration in Siberian permafrost loess-paleosols during glacials
}

\author{
R. Zech ${ }^{1, *}$, Y. Huang ${ }^{1}$, M. Zech ${ }^{2}$, R. Tarozo ${ }^{1}$, and W. Zech ${ }^{3}$ \\ ${ }^{1}$ Geological Sciences, Brown University, Providence, USA \\ ${ }^{2}$ Institute of Geomorphology and Department of Soil Physics, University of Bayreuth, Germany \\ ${ }^{3}$ Institute of Soil Science and Soil Geography, University of Bayreuth, Germany \\ * current address: Geological Institute, ETH Zurich, Switzerland
}

Received: 26 September 2010 - Published in Clim. Past Discuss.: 15 October 2010

Revised: 12 May 2011 - Accepted: 12 May 2011 - Published: 16 May 2011

\begin{abstract}
Recent findings show that the amount of organic carbon stored in high-latitude permafrost regions has been greatly underestimated. While concerns are rising that thawing permafrost and resultant $\mathrm{CO}_{2}$ and methane emissions are a positive feedback mechanism at times of anthropogenic global warming, the potential role of permafrost carbon dynamics on glacial-interglacial timescales has received little attention.

Here we present new results from a well-studied permafrost loess-paleosol sequence in north-east Siberia that almost spans two glacial cycles $(\sim 220 \mathrm{ka})$. We analysed the deuterium/hydrogen isotopic ratios $(\delta \mathrm{D})$ of alkanes, which serve as proxy for paleo-temperature. Thus circumventing difficulties to obtain exact age control for such sequences, the results corroborate our previous notion that more soil organic carbon was sequestered during glacials than during interglacials. This fact highlights the role of permafrost in favouring preservation of soil organic matter. Reduced biomass production during glacials may have been of second-order importance on these timescales.

Although future studies are needed to evaluate existing large estimates of carbon dioxide releases from thawing permafrost during the last termination ( $>1000 \mathrm{Pg} \mathrm{C})$, we suggest that permafrost carbon dynamics contributed to the observed glacial-interglacial variation in atmospheric $\mathrm{CO}_{2}$ and need to be included in carbon cycle and climate models.
\end{abstract}

\section{Introduction}

Antarctic ice cores have revealed that the succession of glacials and interglacials during the past $\sim 800 \mathrm{ka}$ was intimately linked to the global carbon cycle (Petit et al., 1999;

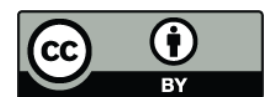

Correspondence to: R. Zech (godotz@gmx.de)
Shackleton, 2000; Luethi et al., 2008). Cold glacial periods were characterized by low concentrations of atmospheric $\mathrm{CO}_{2}$ ( $\sim 180$ to $200 \mathrm{ppm}$ ), while interglacials had high concentrations $(\sim 250$ to $300 \mathrm{ppm})$. The large size of the carbon pool in the ocean ( $\sim 60$ times the atmospheric carbon) led to the prevailing notion that the oceans were the principal driver and acted as net carbon sink during glacials (Sigman et al., 2010; Broecker, 1982; Sigman and Boyle, 2000), which we refer to here as the "ocean hypothesis". Changes in the Southern Ocean in particular have been proposed to play an important role in controlling atmospheric $\mathrm{CO}_{2}$, because upwelling and ventilation of the deep ocean, which constantly accumulates respired $\mathrm{CO}_{2}$ from sinking organic particles, occurs mainly around Antarctica (Sigman et al., 2010; Fischer et al., 2010; Toggweiler et al., 2006).

However, there has been no success so far in finding the supposedly large pool of "old" radiocarbon trapped in the glacial deep ocean, which would be required to corroborate the "ocean hypothesis" (De Pol-Holz et al., 2010; Broecker and Barker, 2007; Skinner et al., 2010). Additionally, carbon models are yet unable to convincingly explain the full range of glacial-interglacial changes in atmospheric $\mathrm{CO}_{2}$ with physical and biological changes in the ocean alone (Brovkin et al., 2007; Fischer et al., 2010; Tagliabue et al., 2009; Kohfeld and Ridgwell, 2010). In light of these inconsistencies, further research is necessary to (i) more precisely quantify glacial-interglacial changes in carbon pools, both in the marine and the terrestrial realm, and (ii) identify mechanisms that may contribute to the observed changes in atmospheric $\mathrm{CO}_{2}$.

What are the current notions concerning the terrestrial carbon pools during glacials? Apart from very few exceptions (Zeng, 2007, 2003), most studies seem to support a "burden" scenario, according to which the terrestrial carbon pools were reduced during glacials, and thus the oceans not only had to take up $\sim 200 \mathrm{Pg} \mathrm{C}$ from the atmosphere ( $\sim 100 \mathrm{ppm}$ change), but additionally the carbon released from the continents.

Published by Copernicus Publications on behalf of the European Geosciences Union. 
Reduced carbon storage on land is in agreement with the intuitive view that net production of terrestrial biomass is lower during glacials, because lower temperatures, lower atmospheric $\mathrm{CO}_{2}$, and increased glacial aridity are less favorable conditions for plant growth. Quantitative estimates based on vegetation models indicate that the "burden" may have been on the order of $\sim 600-800$ Pg C (Joos et al., 2004; Kaplan et al., 2002; François et al., 1998), although much larger figures have been proposed as well (Adams and Faure, 1998). Estimates of 300 to $700 \mathrm{PgC}$ have been derived from $\sim 0.32 \%$ o more negative marine carbon isotopes (Bird et al., 1996; Duplessy et al., 1988) that are commonly interpreted to document a net transfer of (isotopically negative) terrestrial carbon to the ocean.

However, the above estimates for the terrestrial burden may be too high, because organic carbon buried below ice sheets is ignored (Zeng, 2003, 2007), and quantification of soil organic carbon in cold areas does not explicitly consider the important role of permafrost for soil carbon storage. In fact, revised estimates suggest that the soil carbon pools in northern permafrost regions are much larger than previously thought and may exceed $1670 \mathrm{Pg} \mathrm{C}$ (Tarnocai et al., 2009; Zimov et al., 2006). The enormous carbon storage at high-latitudes reflects that apart from biomass productivity, the rate of decomposition is crucial for terrestrial carbon storage. Cold permafrost regions provide very suitable environments for preservation of soil organic matter and longterm carbon storage. Many studies have therefore already fueled concerns that today, at times of global warming, $\mathrm{CO}_{2}$ and methane emissions from thawing and decomposing permafrost soils result in a large positive feedback and accelerate global warming (Schuur et al., 2008; Tarnocai et al., 2009; Zimov et al., 2006).

In order to evaluate the potential role of permafrost soils in the global carbon cycle, information is needed about their age, formation, and carbon dynamics. So far, the lack of long, continuous outcrops spanning several glacialinterglacial cycles has limited such insights. Here we present new results, namely $\delta \mathrm{D}$ of alkanes, from a unique loesspaleosol sequence, which we have studied over the last few years and which documents environmental and climate changes over the last $\sim 220 \mathrm{ka}$. Apart from discussing the new record as proxy for paleo-temperature, we discuss the potential change of the size of the permafrost carbon pool and critically reconsider the current paradigm of the burden scenario.

\section{Material and methods}

Our research site is a $\sim 50 \mathrm{~m}$ high permafrost bluff along the Tumara River in the southwestern foreland of the Verkhoyansk Mountains, northeast Siberia (Fig. 1). The lower part of the bluff exposes Tertiary sands and Quaternary gravels. The upper $\sim 15 \mathrm{~m}$, referred to as "Tumara Paleosol Sequence", consist of frozen dark grey loess-like sediments alternating with bright brown soil horizons (Fig. 2). Previous detailed stratigraphical and geochemical analyses (Zech et al., 2007, 2008) have shown that the dark units (B and D) are dominated by silt size particles and have total organic carbon (TOC) concentrations exceeding $1 \%$. The bright brown units (A, C and E) contain more clay and have much lower TOC $(<0.5 \%)$. These findings have been interpreted to document the succession of glacials and interglacials, with low temperatures favoring intensive permafrost and water logging conditions and good preservation of soil organic matter, while warmer temperatures favor better drainage, mineralization and weathering (Zech et al., 2007, 2008, 2010a).

Radiocarbon and luminescence ages support this interpretation and the correlation of the organic-rich units B and D with the last (MIS 2 to 4) and penultimate (MIS 6) glacials, respectively (Fig. 2). It must be acknowledged though that obtaining robust and precise age control in arctic, partly reworked and weathered loess and paleosols is very challenging. Radiocarbon ages can be significantly too old, because soil organic material is exceptionally well preserved in cold, arctic environments, and re-working of sediments can occur through eolian, fluvial or colluvial processes without oxidation of "old" carbon. On the other hand, the humic acid fraction, which for the above reasons is generally preferred over the refractory humin fraction when dating soils, is more susceptible to translocation, particularly in soils with waterlogging conditions. This can lead to too young radiocarbon ages. Similarly, the IRSL ages can be too old when the samples have been insufficiently bleached prior to deposition (which might explain the inconsistent IRSL age of $177 \mathrm{ka}$ in unit $\mathrm{C} 2$ ), or they can be too young due to signal fading or saturation. For a full discussion of the available numeric ages, the reader is referred to the previous publications (Zech et al., 2010a).

In light of the dating uncertainties, the correlation of the organic-rich units with glacials remained controversial; particularly as palynological and biomarker results became available and documented larch forest cover for unit D (Zech et al., 2010a). This seems to be at odds with its correlation with the penultimate glacial, since larch has traditionally been considered to be an indicator for interglacials in Siberia. Similar inconsistencies are known from Lake El Gygytgyn in NE-Siberia, possibly questioning the validity of using vegetation reconstructions to infer "independent" age control (Brigham-Grette et al., 2007).

In order to circumvent the chronostratigraphical difficulties and to robustly assess the carbon storage and dynamics in the Tumara Paleosol Sequence, we aimed at obtaining direct temperature estimates and measured $\delta \mathrm{D}$ in the long-chain $\mathrm{n}$ alkanes C27, C29 and C31. These n-alkanes are epicuticular leaf waxes synthesized by plants. They are relatively resistant against degradation and well preserved in paleosols, and they are also virtually insoluable in water, prohibiting their vertical migration in soils once deposited (Huang et al., 


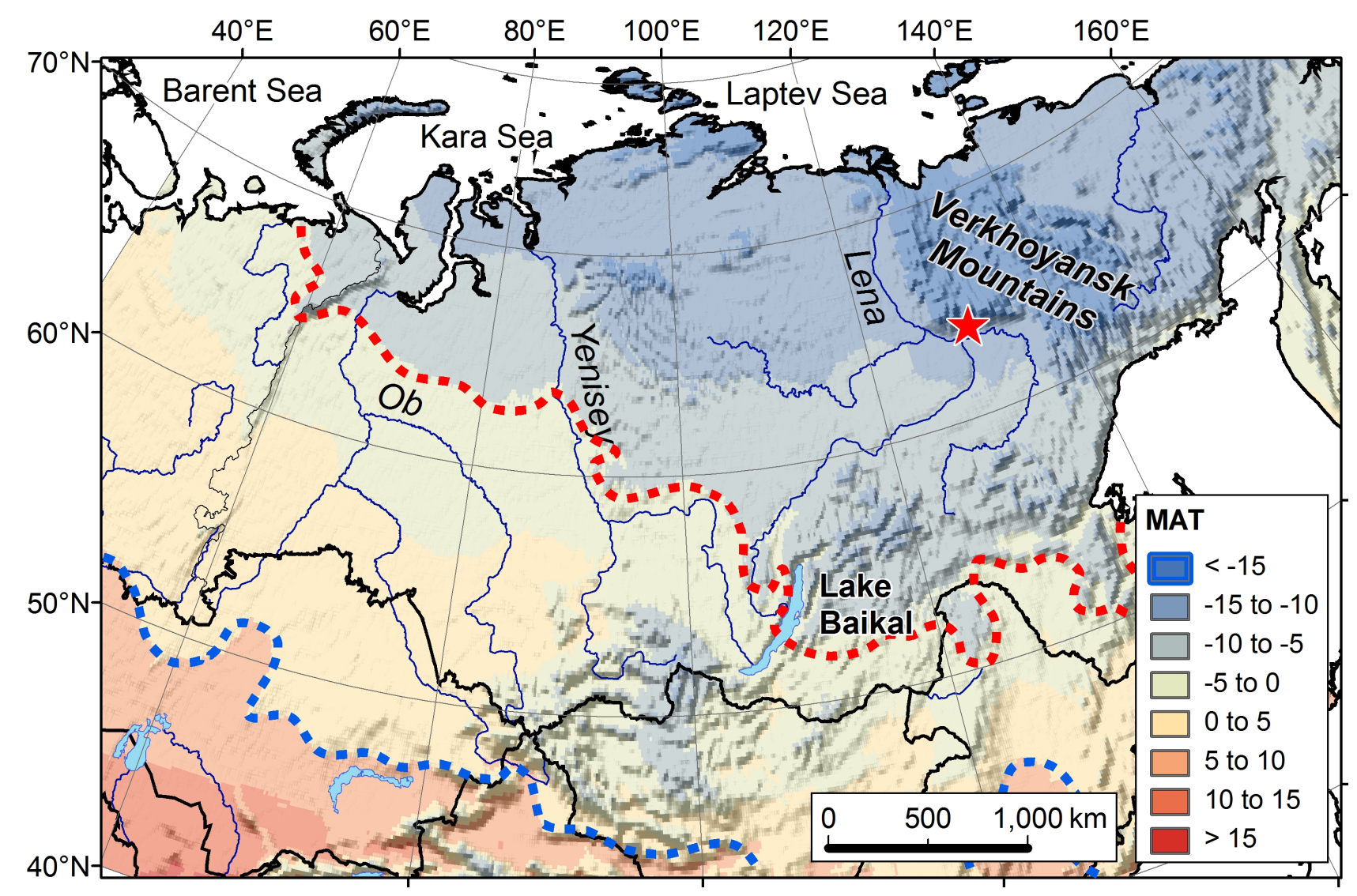

Fig. 1. Geographic setting of the research site and distribution of permafrost soils. The location of the Tumara Paleosol Sequence is indicated by the red star. Mean annual temperatures (MAT in ${ }^{\circ} \mathrm{C}$ ) (New et al., 2002) are draped over a hillshade model. The $-5^{\circ} \mathrm{C}$ isotherm (red dashed line) approximately marks the southward extent of continuous permafrost today (Tarnocai et al., 2009). Discontinuous permafrost exists at MAT $<0{ }^{\circ} \mathrm{C}$, and the $+5^{\circ} \mathrm{C}$ isotherm (dashed blue line) indicates the approximate southward expansion of continuous permafrost during glacials assuming a $10^{\circ} \mathrm{C}$ temperature reduction.

1999). They can thus be employed to reconstruct the $\delta \mathrm{D}$ signal of the water used by the plants during synthesis (Hou et al., 2008; Sachse et al., 2006). Assuming constant metabolic fractionation and limited effects of soil water evaporation (discussed in detail below), the n-alkane signal mainly reflects changes in the isotopic composition of past growth season soil water and thus precipitation. Similar to ice core oxygen and hydrogen isotope records, our leaf wax $\delta \mathrm{D}$ record thus allows inferring past relative temperature changes, with more negative $\delta \mathrm{D}$ values indicating lower temperatures.

The laboratory work followed standard procedures. The air-dried soil samples were ground and extracted with DCM/Methanol (9:1) using accelerated solvent extraction. The total lipid extracts were separated over activated silica columns. The alkane fractions were spiked with hexamethylbenzene for quantification on a GC-FID. Triplicate measurements of the compound-specific deuterium isotope ratios of the alkanes were performed on a GC-pyrolyses-irMS. Standard deviations (shown in Fig. 2) were 2.3, 1.9 and $1.2 \%$ on average for C27, 29 and 31. External standards (C27 and 29) were run every 6 measurements and yielded fairly constant isotope values of $-221.2 \pm 2.8$ and $-186.1 \pm 3.0 \%$.

\section{Results and discussion}

\subsection{Interpretation of $\delta \mathrm{D}$ in terms of relative temperature changes}

The $\delta \mathrm{D}$ records of the three n-alkanes show very similar patterns (Fig. 2). The organic rich units B and D are characterized by values as negative as $-270 \%$, while the alkanes in units $\mathrm{A}, \mathrm{C}$ and $\mathrm{E}$ are more enriched and exceed $-240 \%$. The similarity between compounds suggests that the overall pattern is robustly recording isotopic changes related to temperature and that the potential effects of changing vegetation cover are negligible. Changing vegetation could theoretically have an effect on the reconstructed isotopic signal, because plants may exhibit specific isotopic leaf water enrichments. In fact, vegetation changes have been reconstructed for the Tumara Paleosol Sequence, employing that fact that C27 and 


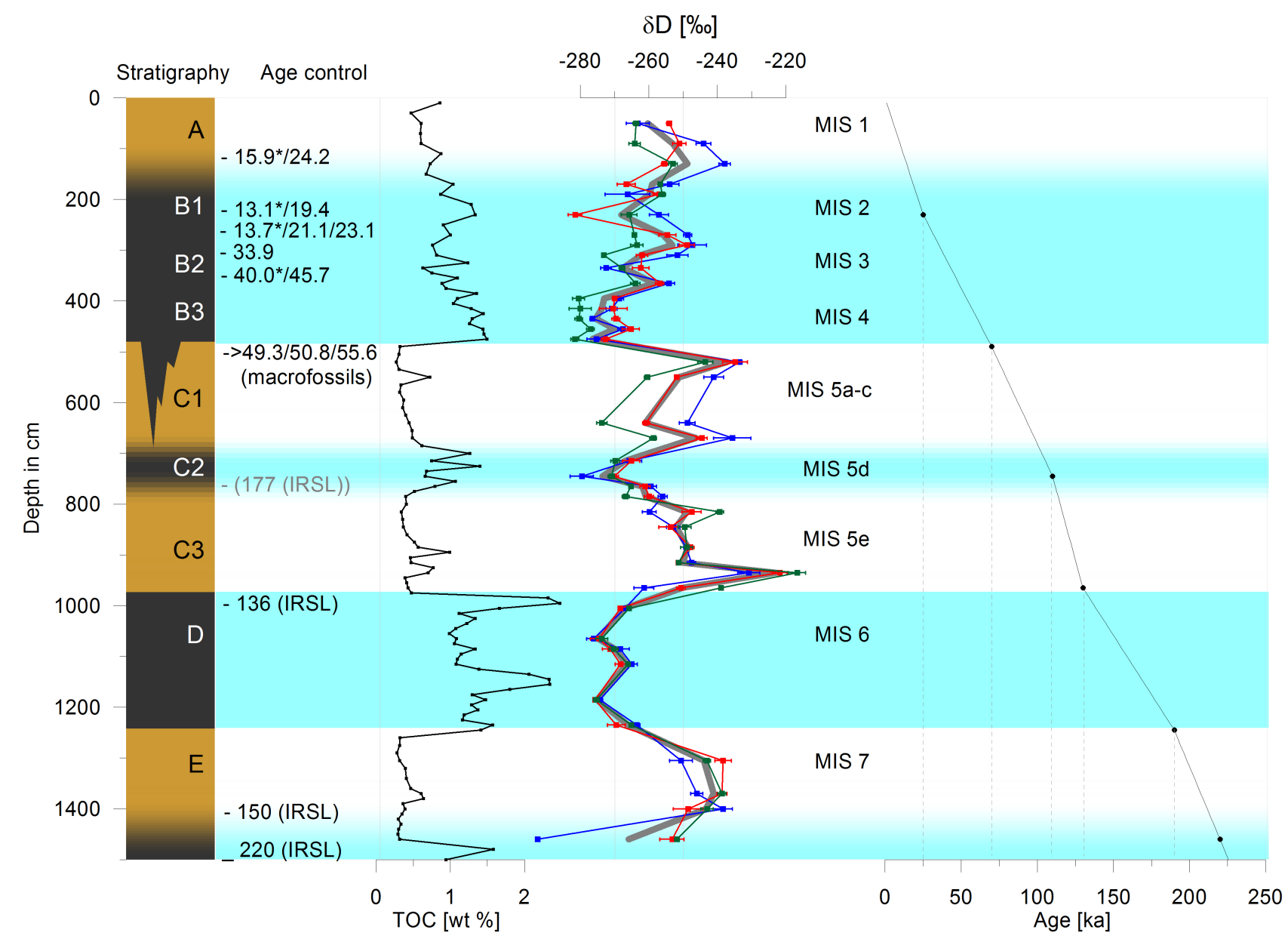

Fig. 2. Stratigraphy and analytical results for the Tumara Paleosol Sequence. The stratigraphy illustrates the distinction between organic-rich, dark grey units (B and D) and bright brown organic-poor units (A, C and E). Calibrated radiocarbon ages (cal. ka BP) have been obtained for the upper part of the profile (* humic acids, others: humins, macrofossils from within the ice wedge), and infrared stimulated luminescence ages (IRSL) for the lower part (Zech et al., 2010a). TOC is the total organic carbon concentration, and $\delta \mathrm{D}$ shows the deuterium/hydrogen isotope ratios measured on the n-alkanes C27, C29 and C31 (in blue, red and green, error bars show standard deviation of triplicate measurements, grey line is the average of all three alkanes). The correlation with marine isotope stages (MIS) and the age-depth model are shown to the right.

29 are dominantly produced by trees, whereas C31 can be mainly attributed to grass (Zech et al., 2010a). As all three n-alkanes show very similar values and patterns (Fig. 2), we suggest that the effect of changing vegetation on the $\delta \mathrm{D}$ signal is negligible.

Evaporation effects are probably also only of second-order importance, because the plants likely could use the soil water close to the thawing front of the active layer, which has not yet experienced the isotopic enrichment that can be expected for the soil water in the uppermost topsoil. Moreover, in their study of leaf wax hydrogen isotopic fractionation across a large gradient of precipitation and evaporation, Hou et al. (2008) did not find a significant influence of aridity on hydrogen isotopic fractionation of plant leaf waxes. Indeed, if evaporation had an effect on our $\delta \mathrm{D}$ record, it would have led to isotopic enrichment during the more arid glacial periods, which would have dampened the observed glacialinterglacial pattern. This could possibly explain the somewhat smaller range of $\delta \mathrm{D}$ values in our record $(\sim 30 \%$ ) compared to respective ranges in ice core records (up to $50 \%$, Fig. 3), and particularly the relatively positive values during the MIS 2.

We finally note that a correction could be applied to our record to take global ice volume changes into account. This would consider the fact that the glacial oceans and thus precipitation became slightly more positive $(\sim 8 \%)$, and applying a correction would further increase the glacialinterglacial differences in $\delta \mathrm{D}$ values. However, such a correction would require relatively precise age control, and we thus prefer to plot the non-manipulated $\delta \mathrm{D}$ record. 


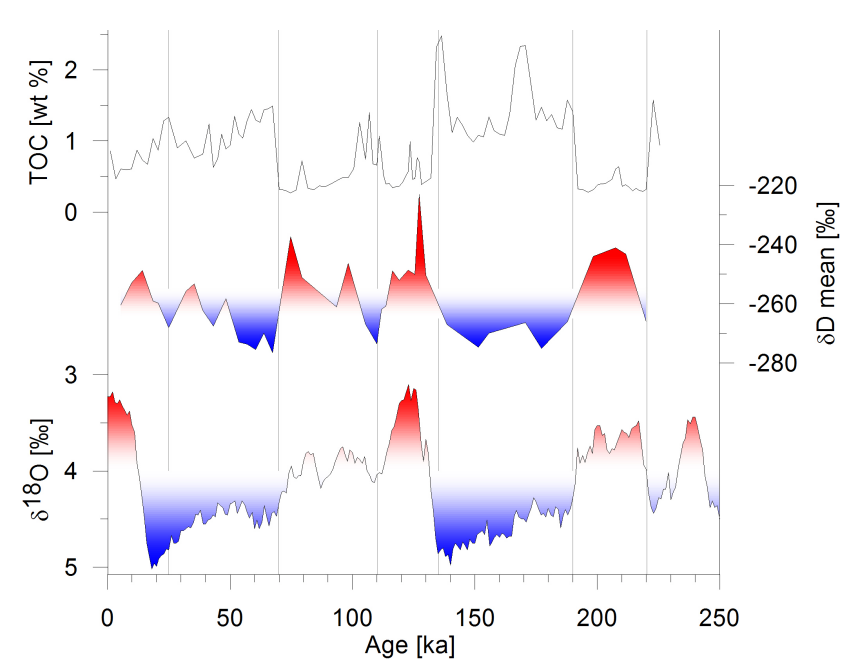

Fig. 3. Comparison of the TOC and $\delta \mathrm{D}$ record from the Tumara Paleosol Sequence with the marine $\delta^{18} \mathrm{O}$ stack (Lisiecki and Raymo, 2005). The vertical grey lines mark the tie points chosen for the age-depth model.

In summary, although we acknowledge the need for further research to quantify and correct for the potential effects of changing vegetation, evaporation, global ice volume and water vapor sources, we suggest that our $\delta \mathrm{D}$ record dominantly reflects temperature, and we infer that units B and D were deposited during particularly cold conditions, namely the last and penultimate glacial.

\subsection{A tentative age-depth model for the Tumara Paleosol Sequence}

In order to construct an age-depth model for the Tumara Paleosol Sequence, we used tie points to match (i) the $\delta \mathrm{D}$ minimum in Unit B1 to the global Last Glacial Maximum, (ii) the $\mathrm{B} / \mathrm{C}$ unit boundary to the MIS 5/4 transition, (iii) unit $\mathrm{C} 2$ to MIS 5d, (iv) the C/D boundary to the penultimate termination, (v) the D/E boundary to the onset of the penultimate glacial, and (vi) the low $\delta \mathrm{D}$ values at the bottom of the profile to MIS 7d (Fig. 3). The respective depth-age pairs are 230/25, 490/70, 745/110, 965/130, 1245/190 and 1460/220 (depths in $\mathrm{cm}$, ages in ka). Given the large methodological uncertainties of the numeric ages, the constructed age-depth model seems plausible. It yields an almost steady age depth model (Fig. 2), which indicates that likely no major changes in sedimentation rates or hiatuses occurred. This is in agreement with the stratigraphical and geochemical results. The ice wedge at $\sim 5 \mathrm{~m}$ depth is the only cryoturbation feature in the outcrop.

We have to emphasize that the constructed age-depth model remains tentative to some degree. However, while flaws in the model could have an effect on the details of the regional paleoclimatic and environmental reconstruction dis-

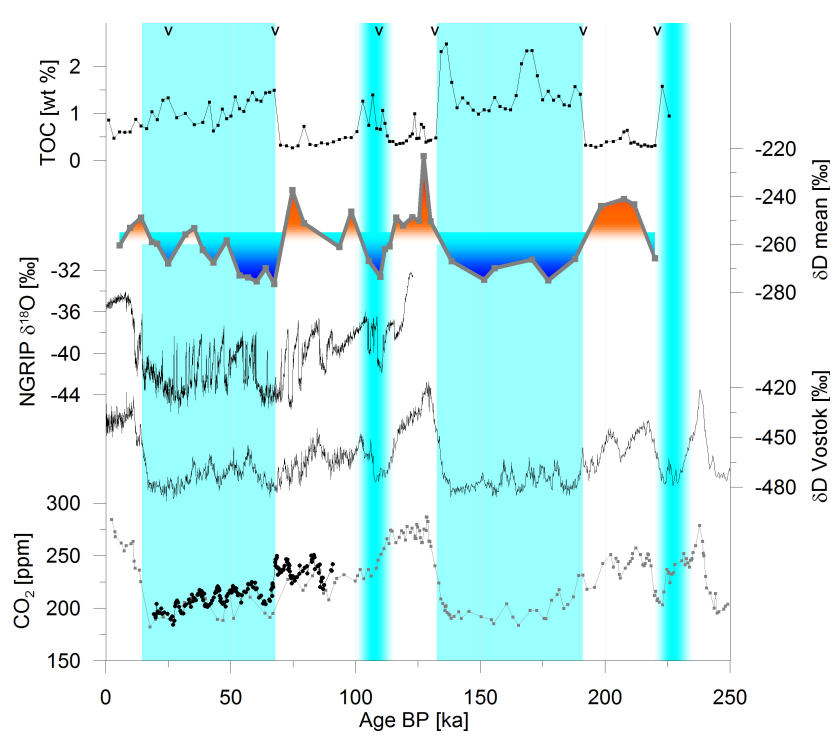

Fig. 4. The Tumara Paleosol record in its paleoclimatic context. The TOC concentration and the mean $\delta \mathrm{D}$ values are compared to temperature proxies from Greenland (NGRIP $\delta^{18} \mathrm{O}$ ) (NGRIP members, 2004) and Antarctica ( $\delta$ D Vostok) (Petit et al., 1999), and to atmospheric $\mathrm{CO}_{2}$ (Ahn and Brook, 2008; Petit et al., 1999). The triangles mark the tie points used to establish the age-depth model.

cussed in the following, our main conclusions drawn in this manuscript are not affected at all.

\subsection{Regional paleoclimatic and environmental reconstruction}

Plotted on an age scale (Fig. 4), our deuterium record reveals good overall agreement with independent paleoclimate data, for instance the isotope temperature proxies derived from Greenland and Antarctic ice cores (Petit et al., 1999; NGRIP members, 2004). This is of course no surprise, and our approach could be criticized to be based on a circular argument, because the marine $\delta^{18} \mathrm{O}$ stack used to construct the agedepth model basically reflects the temperature changes seen in the ice cores. Nevertheless, we are relatively confident that the age-depth model is reasonable, because our record also seems to correctly capture well-known climate patterns in Siberia, such as the early Holocene warmth, warming during MIS 3 (Anderson and Lozhkin, 2001), and peak warmth during MIS 5e (CAPE - Last Interglacial Project Members, 2006; Kienast et al., 2008).

Although the paleoenvironmental reconstruction is not the main focus of this manuscript, we would like to point out two particularly interesting features. First, cold conditions as indicated by unit $\mathrm{C} 2$ are consistent with various findings documenting substantial cooling and glacial advances within the last interglacial during MIS 5d (Zech et al., 2011; Karabanov et al., 1998; Stauch and Gualtieri, 2008). 
Secondly, relatively positive $\delta \mathrm{D}$ values are found for MIS 2. As already mentioned above, this could indicate either extreme arid conditions (evaporation effects), or that the temperatures were relatively modest in NE Siberia. Both interpretations would corroborate plant macrofossil findings from the Laptev Sea coast, which reveal extremely continental, arid conditions characterized by relatively warm summers during MIS 2 (Kienast et al., 2005). Increasing aridity and continentality during the course of the last glacial probably also explain (i) successively more restricted glacial extents in Siberia (Stauch and Gualtieri, 2008; Svendsen et al., 2004; Zech et al., 2011), and (ii) the decline in forest cover and expansion of "Mammoth Steppe" (Zech et al., 2010a; Sher et al., 2005). Explanations for this trend may be found in the lowering of sea level and the resultant distance to the Arctic Ocean, combined with rain shadow effects on the leeside of the growing Fennoscandian and Barents Ice Sheets (Svendsen et al., 2004). However, an intriguing feature is that the penultimate glacial apparently developed differently compared to the last glacial. Glaciers seem to have reached their maximum extents in Siberia at the end of the penultimate glacial (Zech et al., 2011; Stauch and Gualtieri, 2008; Svendsen et al., 2004), and although our $\delta \mathrm{D}$ record indicates very low temperatures, trees and even Larch prevailed (Zech et al., 2010a). Our results may lend support to the controversial hypothesis that the sprawling megafauna itself was responsible for the expansion of the "Mammoth Steppe" and the aridization trend during the last glacial (Zimov et al., 1995).

\subsection{The role of permafrost for enhanced carbon sequestration}

Our results have major implications on the role of permafrost for carbon sequestration. As illustrated in Figs. 24 , more negative $\delta \mathrm{D}$ values (i.e. lower temperatures) correlate with higher TOC concentrations (correlation coefficient $R=-0.61$ ). Note that this correlation is totally independent of the age model uncertainties. We suggest that the correlation reflects the importance of permafrost (as impermeable layer) in favoring water logging, oxygen depleted conditions, and, in combination with low temperature, results in reduced organic matter mineralization and enhanced carbon storage. Net biomass productivity, which was likely higher during warmer periods, was obviously not the dominant factor in controlling TOC concentrations in permafrost soils. Our reasoning is consistent with studies that indicate that increasing biomass productivity in a warming world doesn't offset the effect of permafrost thawing and resultant mineralization of soil organic matter (Schuur et al., 2008; Zimov et al., 2006), as well as with modern analogues, for example the fact that tundra soils preserve and accumulate more TOC than (the more productive) taiga or forest-steppe soils further south.

Permafrost loess sequences along the arctic coast, which are referred to as "ice complex deposits", or "Yedoma" in Russian, often have TOC concentrations exceeding $5 \%$ (Schirrmeister et al., 2002; Wetterich et al., 2008). Most of these sequences, however, span only a few ten thousand years, are discontinuous, and strongly affected by cryoturbation, which limits possible insights into permafrost loess formation and carbon storage on glacial-interglacial timescales. Apart from the ice-wedge at $\sim 5 \mathrm{~m}$ depth, the Tumara Paleosol Sequence shows no evidence for cryoturbation. It thus provides the first field evidence for the temporal dynamics of carbon storage in permafrost soils, documenting enhanced terrestrial carbon sequestration during glacials and reduced sequestration during interglacials/interstadials.

\subsection{Potential size of permafrost carbon sequestration during glacials}

In order to estimate the glacial "excess carbon storage" for the Tumara Paleosol Sequence we did a simple back-of-theenvelope calculation. Using estimated dry soil densities of $1000 \mathrm{~kg} \mathrm{~m}^{-3}$, TOC differences of $1 \%$, and soil thicknesses of $3 \mathrm{~m}$, the glacial units B and D each store $\sim 30 \mathrm{~kg} \mathrm{~m}^{-2}$ excess carbon. When scaled to an area of $10^{6} \mathrm{~km}^{2}$, excess carbon storage would be already $\sim 30 \mathrm{PgC}$, and when considering the possible expansion of permafrost areas during glacials (see Fig. 1), excess carbon storage could be on the order of several hundred Pg C.

Note that our simple up-scaling exercise is only meant to illustrate the direction and order of magnitude of potential permafrost carbon dynamics. Many more long permafrost sequences would ideally have to be studied to come to robust estimates, because local and regional differences in biomass productivity, drainage, mineralization, sediment accumulation rates, etc., need to be taken into account. Nonetheless, we suggest that the permafrost carbon dynamics recorded in the Tumara Paleosol Sequence were (and still are) characteristic for large parts of the vast, non-glaciated areas in Siberia (Fig. 1). Spatial limits were probably reached only at extremely cold sites, where TOC concentrations in soils became production-limited, and at the southern boundary of the Siberian permafrost area, where glacial aridity might have offset the water logging effect of permafrost.

Further insights from additional field studies will be valuable, but may also be limited, because pedological evidence for glacial excess carbon storage in (relict) permafrost soils could, of course, been erased due to mineralization during interglacials. Only where accumulation rates are high enough and where permafrost prevails and protects the carbon-rich, glacial paleosols even during interglacials, the sedimentary stratigraphies will preserve the evidence for glacial permafrost carbon. This, combined with the landscape dynamics and intensive erosion related to permafrost thawing, likely explains why long, continuous paleosol sequences suitable for paleoenvironmental and -climate reconstruction are so scarce and could not be studied more extensively so far. 
Modeling studies may therefore prove to be very helpful in providing more accurate estimates for excess carbon storage in permafrost soils during past glacials. We are aware of only one such modeling study published so far. Zimov et al. (2009) used a permafrost-soil carbon model, which indicates that permafrost soils in Europe and South Siberia may have lost more than $1000 \mathrm{Pg} \mathrm{C}$ upon warming during the last deglaciation.

\subsection{Potential implications for the global carbon cycle}

Even though it is very difficult to quantify the uncertainty of Zimov's figure at this point and future modeling studies are necessary to evaluate and refine this estimate, the potentially enormous size of excess carbon storage in permafrost soils during past glacials strongly suggests that permafrost carbon dynamics could have contributed to the observed variations in atmospheric $\mathrm{CO}_{2}$ concentrations (Fig. 4) and need to be included in global carbon and climate models.

As mentioned in the introduction and acknowledged in many studies, it is difficult to explain the full range of $\sim 100$ ppm difference of atmospheric $\mathrm{CO}_{2}$ concentrations on glacial-interglacial timescales with the current "ocean hypothesis" only and the widely assumed "burden scenario". Permafrost carbon dynamics might provide a simple, hitherto overlooked mechanism to off-set at least part of the terrestrial burden. Taken at face value, Zimov's estimate of $>1000 \mathrm{Pg} \mathrm{C}$ would even result in a "helper scenario" instead (1000 versus 600 to $800 \mathrm{PgC}$ would result in a net release of 200 to $400 \mathrm{Pg} \mathrm{C}$ during terminations). It is certainly challenging to fully and exactly balance the highly uncertain changes in the various terrestrial carbon pools, and further studies are necessary to explore the role of permafrost carbon for the global carbon cycle and the climate system (Zech et al., 2010b, Zech, 2011).

\section{Conclusions}

Our study provides the first deuterium record from Siberian permafrost loess-paleosols and spans almost two glacial cycles. Valuable paleoclimatic information can be inferred directly from this temperature proxy, and future studies shall increase the temporal resolution and test the reproducibility of the record at other sites. The discussion in this manuscript mainly focuses on the robust (sensu independent of the age model) finding that more soil organic carbon was repeatedly sequestered under cold conditions. This finding highlights that changes in mineralization of soil organic material are as important to consider as changes in biomass production, which is in perfect agreement with recent studies showing that the high-latitude soil carbon pools have been hugely underestimated.

While more thorough evaluations of the various terrestrial carbon pool changes (including also peatlands and glacially buried carbon) are needed to come up with robust figures, we suggest that permafrost carbon dynamics may off-set at least part of the hitherto assumed terrestrial burden and thus help to explain the observed glacial-interglacial variability in atmospheric $\mathrm{CO}_{2}$ concentrations.

Interesting implications of our study may also arise for our understanding of the role of high latitude regions for the carbon cycle during the Holocene. Many studies have focused on postglacial peatland development and find rapid carbon accumulation with the onset of the Holocene (Tarnocai et al., 2009; MacDonald et al., 2006; Jones and Yu, 2010). We suggest that while permafrost degradation was dominant during the last termination (from $\sim 17$ to $12 \mathrm{ka}$ ) and may have contributed to the observed rise in atmospheric $\mathrm{CO}_{2}$, peatland formation in the formerly glaciated regions of Siberia and North America started to significantly offset the permafrost carbon emissions since $\sim 12 \mathrm{ka}$ and caused the initial $\sim 7$ ppm drop in atmospheric $\mathrm{CO}_{2}$ during the Early Holocene (MacDonald et al., 2006). Carbon sequestration in peatlands would thus likely have contributed to initiate the next ice age (Franzen, 1994; Klinger et al., 1996), namely by starting the cooling trend and causing further sequestration of carbon in expanding permafrost soils and peatlands. The cooling trend would likely have continued during the Holocene, had there not been man-made global warming and increasing anthropogenic emissions (Ruddiman, 2003), reaching $\sim 5 \mathrm{Pg} \mathrm{yr}^{-1}$ during the last century. To put this emission rate into context, the positive feedback due to thawing permafrost is projected to be $\sim 100 \mathrm{Pg}$ over the next century (Schuur et al., 2008; Tarnocai et al., 2009), while the natural rate of permafrost carbon release during the last deglaciation $(1000 \mathrm{Pg}$ over $5 \mathrm{ka}$, namely from $\sim 17$ to $12 \mathrm{ka}$ ) was probably only on the order of $\sim 0.2 \mathrm{Pg} \mathrm{yr}^{-1}$. We are thus responsible for rapid and unprecedented rates of climate and environmental changes in the Arctic.

\section{Supplementary material related to this article is available online at: http://www.clim-past.net/7/501/2011/ cp-7-501-2011-supplement.pdf.}

Acknowledgements. We thank J. Russell, T. Eglinton, N. Gruber, E. Thomas and J. Zech for discussions and comments on the manuscript. We also appreciate the feedback of several reviewers on an earlier version of this manuscript. This work has partially been funded by DFG grant ZE $154 / 52$ to W. Z. and NSF grants 0902805 and 0816739 to Y. H. R. Z. gratefully acknowledges support through the SNF PostDoc fellowship for advanced researchers.

Edited by: V. Brovkin 


\section{References}

Adams, J. M. and Faure, H.: A new estimate of changing carbon storage on land since the last glacial maximum, based on global land ecosystem reconstruction, Global Planet. Change, 16, 3-24, doi:10.1016/S0921-8181(98)00003-4, 1998.

Ahn, J. and Brook, E. J.: Atmospheric $\mathrm{CO}_{2}$ and climate on millennial time scales during the last glacial period, Science, 322, 83-85, 2008.

Anderson, P. M. and Lozhkin, A. V.: The Stage 3 interstadial complex (Karginskii/middle Wisconsinan interval) of Beringia: variations in paleoenvironments and implications for paleoclimatic interpretations, Quat. Sci. Rev., 20, 93-125, 2001.

Bird, M. I., Llyod, J., and Farquhar, G. D.: Terrestrial carbonstorage from the last glacial maximum to the present, Chemosphere, 33, 1675-1685, 1996.

Brigham-Grette, J., Melles, M., Minyuk, P., and Scientific Party: Overview and significance of a $250 \mathrm{ka}$ paleoclimate record from El'gygytgyn Crater Lake, NE Russia, J. Palaeolimnol., 37, 1-16, 2007.

Broecker, W.: Glacial to interglacial changes in ocean chemistry, Prog. Oceanogr., 2, 151-197, 1982.

Broecker, W. and Barker, S.: A 190 drop in atmosphere's $\Delta{ }^{14} \mathrm{C}$ during the "Mystery Interval" (17.5 to $14.5 \mathrm{kyr}$ ), Earth Planet. Sci. Lett., 256, 90-99, 2007.

Brovkin, V., Ganopolski, A., Archer, D., and Rahmstorf, S.: Lowering glacial atmospheric $\mathrm{CO}_{2}$ in response to changes in oceanic circulation and marine biogeochemistry, Paleoceanography, 22, 1-14, 2007.

CAPE - Last Interglacial Project Members: Last Interglacial Arctic warmth confirms polar amplification of climate change, Quat. Sci. Rev., 25, 1383-1400, 2006.

De Pol-Holz, R., Keigwin, L., Southon, J., Hebbeln, D., and Mohtadi, M.: No signature of abyssal carbon in intermediate waters off Chile during deglaciation, Nat. Geosci., 3, 192-195, 2010.

Duplessy, J. C., Shackleton, N. J., Fairbanks, R. G., Labeyrie, L., Oppo, D., and Kallel, N.: Deepwater Source Variations During the Last Climatic Cycle and Their Impact on the Global Deepwater Circulation, Paleoceanography, 3, 343-360, 1988.

Fischer, H., Schmitt, J., Lüthi, D., Stocker, T. F., Tschumi, T., Parekh, P., Joos, F., Köhler, P., Völker, C., Gersonde, R., Barbante, C., Le Floch, M., Raynaud, D., and Wolff, E.: The role of Southern Ocean processes in orbital and millennial $\mathrm{CO}_{2}$ variations - A synthesis, Quat. Sci. Rev., 29, 193-205, 2010.

François, L. M., Delire, C., Warnant, P., and Munhoven, G.: Modelling the glacial-interglacial changes in the continental biosphere, Global Planet. Change, 16, 37-52, doi:10.1016/S09218181(98)00005-8, 1998.

Franzen, L. G.: Are Wetlands the Key to the Ice-Age Cycle Enigma, Ambio, 23, 300-308, 1994.

Hou, J., D’Andrea, W. J., and Huang, Y.: Can sedimentary leaf waxes record $\mathrm{D} / \mathrm{H}$ ratios of continental precipitation? Field, model, and experimental assessments, Geochim. Cosmochim. Acta, 72, 3503-3517, 2008.

Huang, Y., Li, B., Bryant, C., Bol, R., and Eglinton, G.: Radiocarbon dating of aliphatic hydrocarbons: a new approach for dating the passive fraction carbon in soil horizons, Soil Sci. Soc. Am. J., 63, 1181-1187, 1999.

Jones, M. C. and Yu, Z.: Rapid deglacial and early Holocene expansion of peatlands in Alaska, P. Natl Acad. Sci., 107, 7347-7352,
2010.

Joos, F., Gerber, S., Prentice, I. C., Otto-Bliesner, B. L., and Valdes, P. J.: Transient simulations of Holocene atmospheric carbon dioxide and terrestrial carbon since the Last Glacial Maximum, Global Biogeochem. Cy., 18, GB2002, doi:10.1029/2003GB002156, 2004.

Kaplan, J. O., Prentice, I. C., Knorr, W., and Valdes, P. J.: Modeling the dynamics of terrestrial carbon storage since the Last Glacial Maximum, Geophys. Res. Lett., 29, 2074, doi:10.1029/2002GL015230, 2002.

Karabanov, E. B., Prokopenko, A. A., Williams, D. F., and Colman, S. M.: Evidence from Lake Baikal for Siberian Glaciation during Oxygen-Isotope Substage 5d, Quat. Res., 50, 46-55, 1998.

Kienast, F., Schirrmeister, L., Siegert, C., and Tarasov, P.: Palaeobotanical evidence for warm summers in the East Siberian Arctic during the last cold stage, Quat. Res., 63, 283-300, 2005.

Kienast, F., Tarasov, P., Schirrmeister, L., Grosse, G., and Andreev, A. A.: Continental climate in the East Siberian Arctic during the last interglacial: Implications from palaeobotanical records, Global Planet. Change, 60, 535-562, 2008.

Klinger, L. F., Taylor, J. A., and Franzen, L. G.: The Potential Role of Peatland Dynamics in Ice-Age Initiation, Quat. Res., 45, 8992, 1996.

Kohfeld, K. E. and Ridgwell, A. J.: Glacial-interglacial variability in atmospheric $\mathrm{CO}_{2}$, in: Surface ocean - lower atmospheres processes, Geophysical Monograph Series, AGU, edited by: Saltzman, E. and Quere, C. L., Washington D.C., 2010.

Luethi, D., Le Floch, M., Bereiter, B., Blunier, T., Barnola, J.-M., Siegenthaler, U., Raynaud, D., Jouzel, J., Fischer, H., Kawamura, K., and Stocker, T. F.: High-resolution carbon dioxide concentration record 650000-800 000 years before present, Nature, 453, 379-382, 2008.

MacDonald, G. M., Beilman, D. W., Kremenetski, K. V., Sheng, Y., Smith, L. C., and Velichko, A. A.: Rapid Early Development of Circumarctic Peatlands and Atmospheric $\mathrm{CH}_{4}$ and $\mathrm{CO}_{2}$ Variations, Science, 314, 285-288, 2006.

New, M., Lister, D., Hulme, M., and Makin, I.: A high-resolution data set of surface climate over global land areas, Clim. Res., 21, $1-25,2002$.

North Greenland Ice Core Project members: High-resolution record of Northern Hemisphere climate extending into the last interglacial period, Nature, 431, 147-151, 2004.

Petit, J. R., Jouzel, J., Raynaud, D., Barkov, N. I., Barnola, J.-M., Basile, I., Bender, M., Chappellaz, J., Davis, M., Delaygue, G., Delmotte, M., Kotlyakov, V. M., Legrand, M., Lipenkov, V. Y., Lorius, C., Pépin, L., Ritz, C., Saltzman, E., and Stievenard, M.: Climate and atmospheric history of the past 420000 years from the Vostok ice core, Antarctica, Nature, 399, 429-436, 1999.

Ruddiman, W. F.: The Anthropogenic Greenhouse Era Began Thousands of Years Ago, Climatic Change, 61, 261-293, 2003.

Sachse, D., Radke, J., and Gleixner, G.: $\delta$ D values of individual n-alkanes from terrestrial plants along a climatic gradient - Implications for the sedimentary biomarker record, Org. Geochem., 37, 469-483, 2006.

Schirrmeister, L., Siegert, C., Kunitzky, V., Grootes, P., and Erlenkeuser, H.: Late Quaternary ice-rich permafrost sequences as a paleoenvironmental archive for the Laptev Sea Region in northern Siberia, Int. J. Earth Sci., 91, 154-167, 2002.

Schuur, E. A. G., Bockheim, J., Canadell, J. G., Euskirchen, E., 
Field, C. B., Goryachkin, S. V., Hagemann, S., Kuhry, P., Lafleur, P. M., Lee, H., Mazhitova, G., Nelson, F. E., Rinke, A., Romanovsky, V. E., Shiklomanov, N., Tarnocai, C., Venevsky, S., Vogel, J. G., and Zimov, S. A.: Vulnerability of Permafrost Carbon to Climate Change: Implications for the Global Carbon Cycle, Bioscience, 58, 701-714, 2008.

Shackleton, N. J.: The $100000-$ Year Ice-Age Cycle Identified and Found to Lag Temperature, Carbon Dioxide, and Orbital Eccentricity, Science, 289, 1897-1902, 2000.

Sher, A. V., Kuzmina, S. A., Kuznetsova, T. V., and Sulerzhitsky, L. D.: New insights into the Weichselian environment and climate of the East Siberian Arctic, derived from fossil insects, plants, and mammals, Quat. Sci. Rev., 24, 533-569, 2005.

Sigman, D. M. and Boyle, E. A.: Glacial/interglacial variations in atmospheric carbon dioxide, Nature, 407, 859-869, 2000.

Sigman, D. M., Hain, M. P., and Haug, G. H.: The polar ocean and glacial cycles in atmospheric $\mathrm{CO}_{2}$ concentration, Nature, 466, 47-55, 2010.

Skinner, L. C., Fallon, S., Waelbroeck, C., Michel, E., and Barker, S.: Ventilation of the Deep Southern Ocean and Deglacial $\mathrm{CO}_{2}$ Rise, Science, 328, 1147-1151, 2010.

Stauch, G. and Gualtieri, L.: Late Quaternary glaciations in northeastern Russia, J. Quat. Sci., 23, 545-558, 2008.

Svendsen, J. I., Alexanderson, H., Astakhov, V. I., Demidov, I., Dowdeswell, J. A., Funder, S., Gataullin, V., Henriksen, M., Hjort, C., and Houmark-Nielsen, M.: Late Quaternary ice sheet history of northern Eurasia, Quat. Sci. Rev., 23, 1229-1271, 2004.

Tagliabue, A., Bopp, L., Roche, D. M., Bouttes, N., Dutay, J.-C., Alkama, R., Kageyama, M., Michel, E., and Paillard, D.: Quantifying the roles of ocean circulation and biogeochemistry in governing ocean carbon-13 and atmospheric carbon dioxide at the last glacial maximum, Clim. Past, 5, 695-706, 2009,

http://www.clim-past.net/5/695/2009/.

Tarnocai, C., Canadell, J. G., Schuur, E. A. G., Kuhry, P., Mazhitova, G., and Zimov, S.: Soil organic carbon pools in the northern circumpolar permafrost region, Global Biogeochem. Cy., 23, GB2023, doi:2010.1029/2008GB003327, 2009.

Toggweiler, J. R., Russell, J. L., and Carson, S. R.: Midlatitude westerlies, atmospheric $\mathrm{CO}_{2}$, and climate change during the ice ages, Paleoceanography, 41, PA2005, doi:10.1029/2005PA001154, 2006.
Wetterich, S., Kuzmina, S., Andreev, A. A., Kienast, F., Meyer, H., Schirrmeister, L., Kuznetsova, T., and Sierralta, M.: Palaeoenvironmental dynamics inferred from late Quaternary permafrost deposits on Kurungnakh Island, Lena Delta, Northeast Siberia, Russia, Quat. Sci. Rev., 27, 1523-1540, 2008.

Zech, M., Zech, R., and Glaser, B.: A 240000-year stable carbon and nitrogen isotope record from a loess-like palaeosol sequence in the Tumara Valley, Northeast Siberia, Chem. Geol., 242, 307318, 2007.

Zech, M., Zech, R., Zech, W., Glaser, B., Brodowski, S., and Amelung, W.: Characterisation and palaeoclimate of a loess-like permafrost palaeosol sequence in NE Siberia, Geoderma, 143, 281-295, 2008.

Zech, M., Andreev, A., Zech, R., Mueller, S., Hambach, U., Frechen, M., and Zech, W.: Quaternary vegetation changes derived from a loess-like permafrost palaeosol sequence in northeast Siberia using alkane biomarker and pollen analyses, Boreas, 39(3), 540-550, doi:10.1111/j.1502-3885.2009.00132.x, 2010a.

Zech, R.: A permafrost glacial hypothesis to explain the Pleistocene ice age rhythm, submitted to Quaternary Sci. Rev., 2011.

Zech, R., Huang, Y., Zech, M., Tarozo, R., and Zech, W.: A permafrost glacial hypothesis to explain atmospheric $\mathrm{CO}_{2}$ and the ice ages during the Pleistocene, Clim. Past Discuss., 6, 219902221, doi:10.5194/cpd-6-2199-2010, 2010b.

Zech, W., Zech, R., Zech, M., Leiber, K., Dippold, M., Frechen, M., Bussert, R., and Andreev, A.: Obliquity forcing of Quaternary glaciation and environmental changes in NE Siberia, Quat. Int., 234, 133-145, 2011.

Zeng, N.: Glacial-interglacial atmospheric $\mathrm{CO}_{2}$ changes - the Glacial Burial Hypothesis, Adv. Atmos. Sci., 20, 677-693, 2003.

Zeng, N.: Quasi-100 ky glacial-interglacial cycles triggered by subglacial burial carbon release, Clim. Past, 3, 135-153, 2007, http://www.clim-past.net/3/135/2007/.

Zimov, N. S., Zimov, S. A., Zimova, A. E., Zimova, G. M., Chuprynin, V. I., and Chapin, F. S., III: Carbon storage in permafrost and soils of the mammoth tundra-steppe biome: Role in the global carbon budget, Geophys. Res. Lett., 36, L02502, doi:02510.01029/02008GL036332, 2009.

Zimov, S. A., Chuprynin, V. I., Oreshko, A. P., Chapin, F. S., Reynolds, J. F., and Chapin, M. C.: Steppe-Tundra Transition: A Herbivore-Driven Biome Shift at the End of the Pleistocene, The American Naturalist, 146, 765-794, 1995.

Zimov, S. A., Schuur, E., and Chapin III, F. S.: Permafrost and the Global Carbon Budget, Science, 312, 1612-1613, 2006. 